\title{
Genentech relaunched with independence intact
}

On June 2, Hoffmann-La Roche (Basel, Switzerland) announced its decision to exercise its call option and acquire all outstanding shares of Genentech. This would have ended the independent existence of a company whose initial public offering first inflated the biotechnology bubble back in 1980. But Roche has announced that it will make $19 \%$ of Genentech shares available to the public, surprising those in the industry who thought that the buyback would end what has been a somewhat turbulent few months for the South San Francisco-based biotechnology giant (see Table). Strong sales and a robust pipeline of compounds under development will continue to make Genentech an attractive investment, even though a number of recent clinical results have been disappointing.

The reissuing of Genentech's stock may be a smart move by Roche. By retaining some independence and taking a business-as-usual stance, Genentech will likely avoid the much-anticipated exodus of top scientists and managers that might have followed the company's submersion into its corporate parent.

The purchase will cost Roche more than $\$ 4$ billion, but the redemption price of $\$ 82.50$ per share was well below Genentech's $\$ 86.50$ price at the close of trading on June 2. One week after the announcement, Genentech shares were trading just over $\$ 82$. The Roche decision is "a great victory" for Genentech, which has been operating under an unclear vision of its future for the past nine years, observes Joel Sendek, senior vice president and biotechnology analyst at Gerard Klauer \& Mattision (New York). Short-term losers were Genentech investors, who, while applauding Genentech's independent status, were not able to capitalize on the agreement. "You might see some short-term dampening of investor interest," says Sendek.

Roche also renegotiated its commercialization agreement with Genentech, extending it to 2015, and modifying its licensing option. Whereas previously Roche could exercise its option to license any future product that Genentech decided to take into development at the end of phase II trials, under the new agreement, Roche can now make a payment to Genentech at the end of phase II that extends its right to license until the end of phase III trials.

Another significant, if ultimately unresolved, recent event for Genentech was the end of the jury trial over disputed rights to human growth hormone. Nine years after the University of California at San Francisco originally alleged that Genentech had illegally obtained materials that underpinned its patents on

Vicki Glaser is a freelance writer working in Allentown, PA. human growth hormone, the matter finally came to the courtroom in April. Six weeks later, although eight of nine jurors sided with UCSF, the trial was deadlocked, sparing Genentech defeat and hefty damages. UCSF contended that Genentech scientist, Peter Seeburg, had gone back into his USCF laboratory in 1978 and taken DNA samples that included clones containing human growth hormone sequences. According to the university, these samples became the basis for Genentech's patent on human growth hormone and its subsequent products Protropin, Nutropin, and Nutropin AQ, which had combined annual sales of $\$ 214$ million in 1998 .

However, it has been sales of Genentech's breast cancer drug Herceptin, and the monoclonal antibody Rituxan, indicated for the treatment of B-cell non-Hodgkin's lymphoma, that have contributed most to a recent strong increase in revenues. First-quarter product sales were up $42 \%$ in 1999 , compared to the first quarter of 1998, with overall revenues up $22 \%$ to $\$ 322.3$ million. During the second half of 1998, Genentech's stock price had dipped into the low $\$ 60$ s and peaked near $\$ 75$, but the surge in product sales sent the share price to approach the $\$ 90$ mark in the first half of this year.

Analysts expect that there is more to come: sales of Herceptin will top \$200 million in 1999, and Rituxan sales will reach $\$ 275$ million, predicts Meirav Chovav, biotechnology analyst at Salomon Smith Barney (New York, NY).

"Genentech is one of the, if not the most well-positioned biotechnology companies," says Sendek, citing the diversity of their product offering and the depth and strength of their pipeline. The company is planning to file a new drug application for Nutropin Depot soon, and both its anti-IgE humanized monoclonal antibody to treat asthma and allergic rhinitis, and Xubix (licensed to Roche), an oral antagonist of platelet aggregation in acute coronary syndrome, are moving through phase III trials. Piv- otal trials are also underway to evaluate Rituxan for use in combination with standard chemotherapy in previously untreated patients, and to assess the long-term effects of Pulmozyme, a recombinant form of the enzyme DNase 1, in early intervention in cystic fibrosis. Genentech will also move its anti-CD11a monoclonal antibody (developed in collaboration with Xoma, Berkeley, CA) into phase III trials as a treatment for psoriasis.

However, it hasn't all been good news. The company announced in April that it will not file a biologics license application for nerve growth factor following its poor showing in a phase III trial to treat diabetic peripheral neuropathy. The preliminary data showed that rhNGF did not improve nerve function after 12 months of treatment. Likewise, vascular endothelial growth factor, a drug to promote angiogenesis, or blood vessel growth, was disappointing in a phase II trial in patients with coronary artery disease (Nature Biotechnology, 17, 326). "Genentech can withstand multiple high-profile failures without really denting the strength of its pipeline," says Sendek.

Sales of Activase, Genentech's recombinant tissue plasminogen activator (TPA), were down, dropping nearly $7 \%$ from a year ago, to \$52 million. But in March, the company reported promising results of a phase III trial of another version of TPA, tenecteplase, in heart attacks. Tenecteplase is given as a single dose, and is designed to have a longer half-life and increased specificity for fibrin. It is likely to go before the US FDA and the European Medicines Evaluation Agency (EMEA; London) during the third quarter of 1999. The challenge for tenecteplase will be to boost sales despite a waning thrombolytic market and competition from Centocor's (Malvern, PA) Retavase, another TPA variant and one that Hoffmann-La Roche had to license out when it bought Boehringer Mannheim in 1998 (Nature Biotechnology, 16, 316).

Vicki Glaser

\begin{tabular}{|c|c|}
\hline $\begin{array}{l}\text { - Roche buys rest of Genentech shares at } \$ 82.50 \text {, but intends to } \\
\text { maintain company's independence. } \\
\text {-Hung jury in University of California at San Francisco's patent } \\
\text { infringement lawsuit spares Genentech more than } \\
\$ 1 \text { billion in potential damage payments; but threat } \\
\text { remains pending a second trial. } \\
\text { - First-quarter revenue growth reflects continued strong sales of } \\
\text { Herceptin and Rituxan. } \\
\text { - Settlement with US government regarding illegal promotion of } \\
\text { human growth hormone costs company } \$ 50 \text { million } \\
\text {-Positive phase III trial results reported for new clot buster } \\
\text { Tenecteplase. } \\
\text { - Clinical disappointments for human nerve growth factor and } \\
\text { vacular endothelial growth factor. }\end{array}$ & $\begin{array}{l}\text { (June 99) } \\
\text { (April 99) } \\
\text { (April 99) } \\
\text { (March 99) } \\
\text { (April 99, February 99) }\end{array}$ \\
\hline
\end{tabular}

